\title{
Medical Humanities in Clinical Rotation of Forensic Medicine and other Clinical Setting
}

\author{
$\underline{\text { Taufik Suryadi }}^{1}$, Kulsum $^{2}$ \\ ${ }^{1}$ Department of Forensic Medicine and Medicolegal, Faculty of Medicine, Universitas Syiah Kuala \\ Banda Aceh, Indonesia \\ ${ }^{2}$ Department of Anesthesiology and Intensive Tharapy, Faculty of Medicine, Universitas Syiah Kuala \\ Banda Aceh, Indonesia \\ Email: taufiksuryadi@unsyiah.ac.id
}

\begin{abstract}
:
Humanities is one of the pillars of science taught at the Faculty of Medicine. The humanities approach to medicine is believed to be able to provide increased professionalism for doctors in providing services to patients. Several teaching methods have been developed to incorporate medical humanities into the curriculum, including through the approaches of spiritualityreligiosity, arts and literature, and narrative medicine. The integration of humanities in medical education can be done by showing professional attitude, communication skills, introspective and practice of self-reflection. In clinical rotation of forensic medicine, medical humanities have been applied to students. One way to implement medical humanities is through several concept approaches, namely religion, bioethics, health law, sociology of medicine and professional behavior.
\end{abstract}

Keywords:

clinical rotation; clinical setting; forensic medicine; medical humanities

\section{Introduction}

Medical education in Indonesia currently refers to the 2019 Indonesian National Professional Education Standards (Standar Nasional Pendidikan Profei Dokter IndonesiaSNPPDI). The 2019 SNPPDI is a continuation of the 2012 Indonesian Doctors Competency Standards (Standar Kompetensi Dokter Indonesia-SKDI) in 2012 with several additions. Based on 2019 SNPPDI, the competence of a doctor is built with 9 competency areas including noble professionalism, self-insight and personal development, effective communication, information and communication technology literacy, scientific literacy, clinical skills, management of health problems and resource management, collaboration and work together, patients safety and the quality of health services. One method of achieving the competency of a doctor is by conducting clinical rotation. In accordance with the SNPPDI issued by the Indonesian Medical Council (Konsil Kedokteran Indonesia-KKI) in 2019, that medical education has four scientific pillars namely basic biomedical science, social science and medical humanities, medical science and clinical skills, public health / preventive medicine / community medicine (KKI, 2019).

According to the 2019 SNPPDI, the sciences of medical humanities include health behavioral sciences, medical sociology, medical anthropology, religion, bioethics and health law, languages, Pancasila and citizenship. In an effort to achieve competence, in the clinical rotation of forensic medicine in the Faculty of Medicine Syiah Kuala University refers to the 2019 SNPPDI by selecting topics related to each area of competence, specifically in this paper discussed about medical humanities related to forensic medicine and some the other clinical settings. 


\section{Review of Literatures}

Medical humanities are very potential in professional improvement and the application of humanistic aspects in medical education, but have not yet been incorporated into the medical education curriculum specifically in the clinical rotation of the Faculty of Medicine at Syiah Kuala University. But explicitly at this time in the clinical rotation of the forensic medicine, medical humanities have been applied to students. One way to implement medical humanities is through several concept approaches, namely:

\subsection{Religion}

The application of religious values in clinical rotation is in the form of the belief that religion as a moral value determines human attitudes and behavior. Building an understanding of the importance of aspects of outward religiosity (Islam) and inner spirituality (Faith and Ihsan) in the practice of forensic medicine, so students are not only capable and competent cognitively, skillfully, and in attitudes must also increase the level that both in conducting education and providing medical services are intended solely for worship of God (Assegaf, 2006).

It also needs to be discussed about aspects of religion in medical practice. In medical education there are several medical issues that need to be reviewed from the religious aspect to see whether a medical action is appropriate or not in accordance with religious teachings. In the clinical rotation of forensic medicine, the perspective of Islamic religion is discussed in relation to several issues such as autopsy, grave excavation, euthanasia, end of life, identification, abortion, child murder, rape, emergency services, signs of death, suicide, murder, etc.

In addition to health factors, religious beliefs are the main factor that encourages consumers to consume cosmetics. Knowledge of religious beliefs or belief is the best guide for knowing which cosmetics can be used. According to Said (1997) Islam is a system of beliefs and comprehensive actions that govern faith, individuals, and society and transcend the material world. The main basis of Islamic rule is Shari'ah. Shari'ah Islam regulates all aspects of life including consumption behavior. (Hasibuan, 2019)

In carrying out clinical rotations, a medical student must also treat patients / victims, both living and dying as a human unit with a complete biopsychosocultural and whose dignity must be respected. Medical students during clinical rotation can explore religious values in the framework of a humanistic approach to patients and their families. Some examples of humanistic values that rely on religious and spiritual values include entertaining families who are overwritten by disaster. They need encouragement and peace of mind so they can get through all these trials. In the examination must be careful, professional, attentive and polite. Islamic service principles are also carried out such as maintaining confidentiality, not telling about the matter of the body, not opening genitals and always guarding the feelings of patients / victims and their families (Koenig, 2004; D'Sauza, 2007; Suryadi, 2017).

\subsection{Bioethics}

Globally, bioethics is a great science that overshadows the whole of science, both science-technology and social-humanities. Forensic medicine itself is a combination of these two scientific fields. Today many forensic specialists and other specialist doctors are involved in and concentrating in the field of bioethics. Moreover, many bioethics are also related to ethics and medicolegal which is one of the subspecialties of forensic medicine. Several 
forensic specialists today have many PhDs in Bioethics, the Master of Bioethics, the Master of Science in Bioethics, and the Diploma in Bioethics. In the future the development of bioethics will be even more advanced with the number of bioethics and medical humanities studies centers formed in several faculties of medicine in Indonesia (Jacobalis, 2005; Darmadipura, 2005).

In daily clinical practice, students are faced with ethical issues, what students must do is to prioritize moral principles in medicine, which is to provide benefits (beneficence), not detrimental (non-maleficence), fair (justice) and respect for patients / victims (autonomy). In examinations of patients / victims must be with the permission of the patient or his family, should not be carried out in groups to respect the privacy and comfort of the patient / victim (Beauchamp and Childress, 2013).

In addition, students also need to apply clinical ethics in their medical practice. Some clinical topics related to forensic medicine are medicolegal issues such as the determination of the end of life and ethical dilemmas in clinical cases. In medical decision making it can also be done with a humanities approach. Students are taught that in making medical decisions based on ethical decisions, the humanities aspects also play a role in them. As done by Jonsen, Siegler, and Winslade, by including the patient's quality of life and socio-cultural factors when making ethical decisions (Jonsen et al., 2010).

\subsection{Health Laws}

There are several situations in which medical science is "related" to law. First, medical law (law for medicine) or medical law is a branch of law and specialized in legal science. Second, medicolegal (medical for law), which is a branch of medical science, medical specialty. Third is forensic medical science (medical jurisprudence, judicial medicine, medical forensic). At present the science is better known as forensic and medicolegal medicine (Amir, 2013; Dahlan \& Trisnadi, 2019).

Nowadays Health Science is growing rapidly, with many forensic specialists and other specialist doctors interested in taking master's degrees for this field of study, the academic degree is the Master of Health Law. But forensic medicine must be distinguished from health law because the point of application is different, forensic medicine is medicine for the law, while health law is law for medicine (law for medicine) (Dahlan, 2005).

Briefing about the importance of doctor's responsibilities in law and public order. Students must realize that being a doctor is not only to provide treatment to patients, it must also provide medicolegal services for a sense of justice for patients. Conscious and law-abiding material provided in the form of: (a) the ability to identify legal problems in medical services and provide advice on how to solve them, (b) be aware of doctors' responsibilities in law and public order, (c) obedience to applicable laws and regulations , (4) able to provide assistance to law enforcement for justice.

\subsection{Sociology of Medicine}

Respect for the sociological values of patients and their families is of high importance in medical education. Likewise, respect for the customs and norms prevailing in the community is very necessary. In conducting forensic medical examinations in hospitals, it is always tinged with traditional customs and norms that have been taking place so far with nuances of Islamic sharia, such as autopsy and exhumation. 
Refusal of an autopsy, exhumation or extracurricular examination can be respected as long as the importance and benefits of the action have been explained. Due to Islamic sharia reasons too, the holding of the corpse (fardhu kifayah) must also be hastened, the examination carried out as soon as possible. The services performed on the body must also reflect the Islamic services provided by the hospital (Haneef, 2006).

\subsection{Professional Behavior}

In clinical rotation of forensic medical, students are also given guidance on the importance of professional attitude in every act of forensic medicine. Every student is expected to have an attitude of professionalism that is responsible, teamwork, interpersonal and inter-professional relations, attitudes and behaviors that are accountable to the community, both the professional community and the wider community (Lari, 2001).

Other supporting principles are the responsibilities of modern medical professionalism, with a commitment to: (a) enhance professional competence; (b) be honest with patients; (c) maintain patient confidentiality; (d) maintaining relationships that fit the patient's needs; (e) improve the quality of care; (f) increase access to care; (g) conduct an equitable distribution of limited resources; (h) increase scientific knowledge; (i) maintaining trust by managing conflicts of interest; and professional responsibility (Cruess et al., 2009; Wong et al., 2012).

\section{Discussion}

\subsection{Definition of Medical Humanities}

What is medical humanities, and why is it important in medical education at this time? Actually medical humanities are nothing new in medical education. History has recorded that medical humanities began in 1920, through a well-known article which states that "the secret of treating patients is caring to patients". The integration of humanities in medical education can be done by showing professional attitudes, communication skills, introspective and practice of self-reflection (Wald et al., 2019).

Medical humanities have several meanings in the medical literature, sometimes often overlapping with medical ethics. This program seriously develops collaboration between humanist, scientific, medical and other aspects, which believes that doctors will place a human touch on medical practice, despite the increasing medical technology (Alabi et al., 2008). The fundamentals of medical humanities are inclusive defined as a collection of humanities sciences, namely literature, philosophy, history, art, music, cinema, theater, law, economics, politics, theology and anthropology, religious aspects and spiritual experiences (Gillon, 2000). According to Shapiro et al (2009), medical humanities are methods, concepts, and contents of one or more of the humanities disciplines for researching illness, pain, disability, hope, healing, treatment relationships and other aspects of medicine and practice health care.

Learning activities in the clinical rotation of forensic medicine in the Faculty of Medicine, Syiah Kuala University is currently using an integral approach between sciencetechnology and social humanities. This is believed to make it easier for someone to become a good doctor with a balance between science, technology, social and humanity. Sciencetechnology is given by applying medical science and technology while social humanities is carried out with professionalism, behavior and humanism approaches in medicine. (Macnautghton, 2000; Suryadi, 2017). The integration of science-technology with social humanities can be described as follows: 


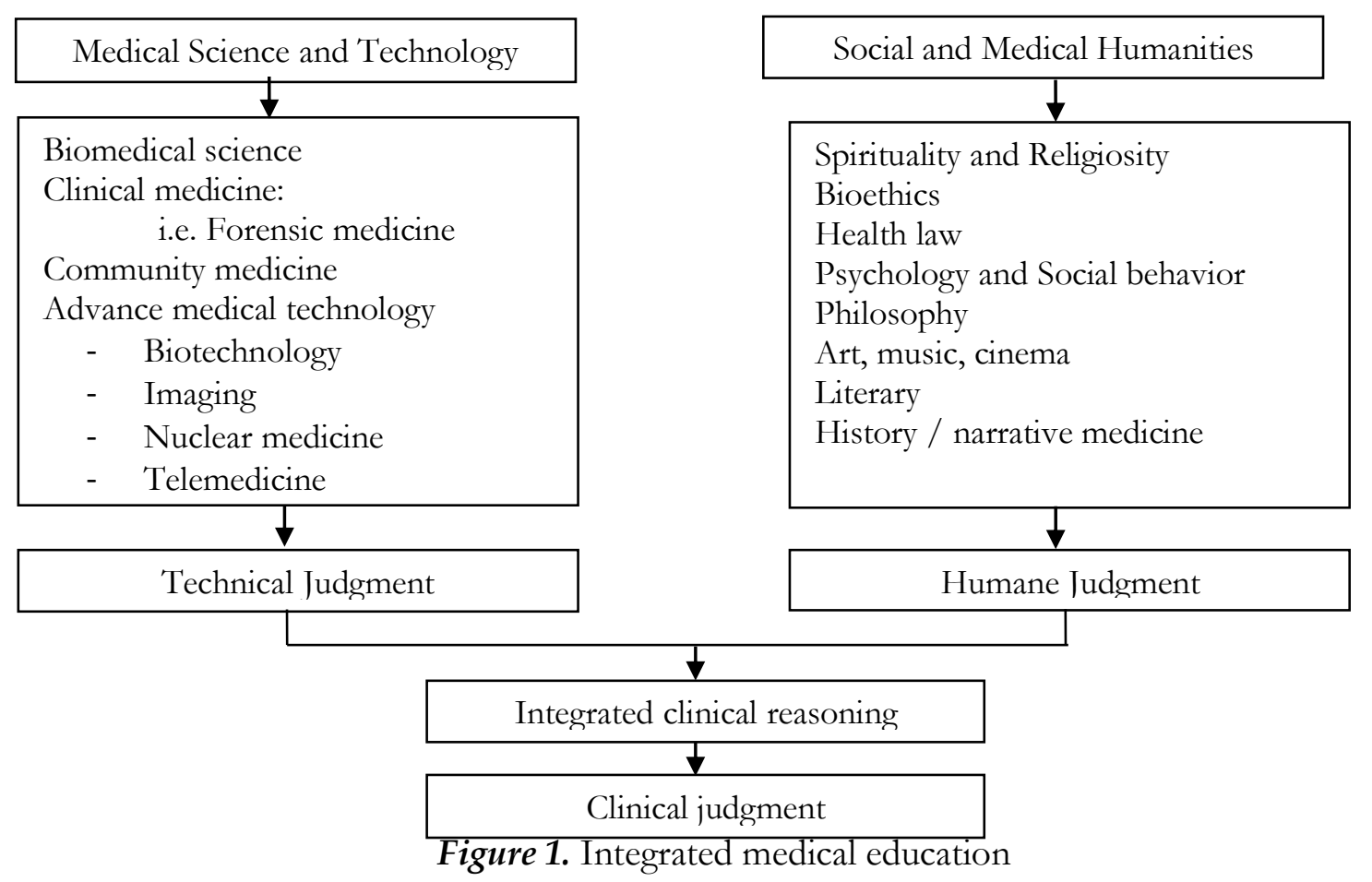

The core of medical services is care, compassion, attention and empathy. It will be a problem if medical students and residents have lost empathy with patients. When the empathic relationship of the student with the patient is broken, the patient will experience worse care (Jones, 2014). Research conducted by Graham et al (2016) found that empathy given by doctors was highly valued by the community, patients, and their families. Empathy is also an added value of professionalism, and is strongly associated with better clinical outcomes.

The study also found that if there was less empathy from doctors, the patient's suffering would increase. For this reason, in medical education empathy training is needed to preserve and increase students' empathy towards patients. Almost the same as research conducted by Horton (2019), that students in their clinical rotation activities must learn to understand the story and life journey of patients, students must learn not only the scientific basis of disease but also the personal and human aspects of the disease.

Wong et al (2012) have also conducted research related to medical humanities. The result is that professionalism and humanistic education in clinical medicine refer to how to teach medical students about patient welfare, patient autonomy and social justice. Medical humanities are defined as one of the main items for evaluating medical education and being an important part in achieving medical professionalism. As it is known that medical professionalism has several basic principles namely the priority of patient welfare, patient autonomy and social justice (Wong et al., 2012).

The issue of humanistic needs becomes very potential taught at the academic level, clinical rotation and practice. At the academic level, less attention to the humanities is still relatively. In medical training, with the exception of palliative care texts and ethical courses and seminars, medical humanities are not considered directly, although consideration of humanities is one of the patient's rights and needs to be discussed (D'Sauza, 2007). 


\subsection{How to Teach It in Clinical Settings}

The main problem about how to teach humanities in medical education is such a tight schedule of student activities because students study medicine in the health care system that does not prioritize care, students conduct patient examinations, prepare supporting examinations and interpret tests, formulate treatment plans, and supervise patients who sometimes sometimes students handle patients in the same shift so that due to time pressure and the demands of the education process empathy and compassion are ignored. (Jones, 2014).

The lecturers have long worked to find the best way to teach medical knowledge and skills. While how to teach humanities is still in the preparation of a curriculum that is still in process. Although currently, the medical education curriculum has sought to find the best way about teaching humanities because it needs to be realized that the humanities are likely to be as important as the technical expertise of a doctor (Jones, 2014). Medical humanities have been proposed as activities that can increase empathy in medical students by developing skills such as narrative interpretation and the ability to manage situations (Graham et al, 2016). The humanities method for medical students has been shown to improve some of the clinical skills of students such as fine arts, by paying attention to fine arts so students can be given an understanding of empathy and will improve observation skills in physical diagnosis (Graham et al, 2016).

\section{a. Spiritual and Religious Approach}

Medical students during clinical rotation can explore religious values within the framework of a humanistic approach to patients. Some examples of humanistic values that rely on religious and spiritual values include entertaining the patient. The patient are very weak people because they are being tested and tried with diseases by Allah Subhanahu Wa Ta'ala. They need encouragement and peace of mind so they can get through all these trials, realize that illness is only temporary and there is a limit, and there is hope for recovery and good return (Ondigo, 2010). Allah Subhanahu Wa Ta'ala said: "In fact, in every difficulty there is ease. Surely in every difficulty there is ease "( Al Qur'anul Karim, Al-Insyirah 5-6). Students can also provide moral support to patients and their families by expressing a few sentences of entertainment, for example stating that illness actually intends to strengthen beliefs in the truth and can erase sin, because for any misfortune, illness, anxiety, grief, or pierced by thorns Allah Subhanahu Wa Ta'ala will remove sin from him (Haneef, 2006).

Students can also build optimism in patients. If the patient is hopeless from recovery, the young doctor (student) should always provide an optimistic feeling and positive hope to the patient, bringing him good news and a desire to recover. Students can build patient optimism by conveying optimistic sentences, for example, that believers must not despair from Allah's trials, Allah has revealed the distress of the Prophet Ayyub ub Alaihissalam, restoring the vision of the Prophet Ya'kub 'Alaihissalam. God is also the one who reveals all troubles and disasters, restores health, and replaces from illness to health, from weak to strong (Ramadhan, 2004). Empathize the patient by feeling the patient's pain. In an Islamic society, sick people do not feel alone. The togetherness of the feelings of those who surround him, and the prayers that flow has alleviated the pain and disaster that befell him. This is really the peak of human charm, the height of humanity's nobility.

\section{b. Approach of Art and Literature}

Art works can be in the form of fine arts, painting, sculpture, film, music, or drama, which are mostly performed by medical institutions to provoke students' empathy values. In a painting of a doctor who is very concerned about pediatric patients, will bring the imagination 
of students to find the humanistic side of the doctor. There is also a method of using film as a teaching medium to students very well used in medical education, this method is often called "cinemeducation". There are three ways to approach humanities learning through film, namely (a) the film portrays explicitly how a doctor behaves, (b) the film provides exemplary experiences for education, training and practice, (c) the film illustrates the biopsychosocial role of a doctor in the community (Silenzio et al., 2006). Likewise with the method of using literary works, recent data shows that there is an increase in cognitive capacity that allows people to understand the mental condition of others by reading literature, as well as improving empathic skills in doctor and patient relationships (Graham et al, 2016).

\section{c. History / Narrative Medicine Approach}

Another approach to teaching humanities in medicine is by "narrative medicine". The doctor must be able to understand the patient's feelings outside the context of his illness in the form of his hopes, his sufferings, his treatment choices and quality of life (Horton, 2019). Two approaches of narrative medicine for medical humanities learning are traditional and humanistic methods. The traditional model is defined as a face-to-face teaching and learning process with a teacher-centered approach and predetermined learning objectives. The humanistic model is a learning journey where there is collaboration between lecturers and students in achieving learning objectives. In other words, the humanistic learning model is interactive in medical education. Both of these learning methods show success in advancing student humanistic practices (Wong et la., 2012; Cruess et al., 2009). Thus, to hone the skills of students in making medical decisions can also be done by listening and interpreting the words of patients so that students can read and think more critically (Horton, 2019).

\section{Conclusion}

The current Indonesian medical education core curriculum through SNPPDI 2019 has explicitly integrated aspects of medical humanities in medical education so that it is the duty of the medical faculty to create a curriculum that contains how aspects of humanities and professionalism can contribute to the formation of an ideal doctor. In-depth studies are needed on how to educate students on clinical rotation in order to be able to apply the humanities and professionalism aspects in their practice in hospitals.

\section{References}

Alabi AO, Ogunyade TO, Zaid YA. 2008. Humanities in Medical Education and Patient care: Lessons from sense Colleges of Medicine in Nigerian Universities. Health and Bioesciences Lib. Quebec. Canada.

Amir A. 2013. Rangkaian Ilmu Kedokteran Forensik. 3rd ed. Departemen Kedokteran Forensik Fakultas Kedokteran Universitas Sumatera Utara. Medan.

Assegaf A.R. 2006. Pendidikan dalam Studi Keislaman: Analisis domain Kognitif, Psikomotorik dan Afektif. Dalam Sosial Humaniora dan sains dalam Studi Keislaman. Lembaga Penilitian UIN Sunan Kalijaga Yogyakarta.

Beauchamp, T.L., Childress, J.F. 2013. Principles of biomedical ethics (7th ed). New York: Oxford University Press.

Cruess RL, Cruess SR, Steinert Y. 2009. Teaching Medical Professionalism. Cambridge University Press.

Dahlan S. 2005. Hukum kesehatan-rambu-rambu bagi profesi dokter. Edisi 3, Badan Penerbit Universitas Diponegoro Semarang. 2005.

Dahlan S, Trisnadi S. 2019. Ilmu Kedokteran Forensik. Fakultas Kedokteran Universitas Sultan Agung. Semarang. 
Darmadipura MS. Kajian Bioetik. 2005. Unit Bioetik Fakultas Kedokteran Universitas Airlangga. Surabaya.

D’Souza R. 2007. The Importance of Spirituality in Medicine and Its Application to Clinical Practice. Psychiatric Annals 36: 3. March 2006.

Graham J, Benson LM, Swanson D, Potyk D, Daratha K, Robert K. 2016. Medical Humanities Coursework Is Associated with Greater Measured Empathy in Medical Students. The American Journal of Medicine. 129: 1334-1337.

Gillon R. 2000. Welcome to Medical Humanities and Why. Journal of Medical Ethics; 26: 1556.

Haneef SIH. 2006. Ethics and Fiqh for Daily Life an Islamic Outline. International Islamic University Malaysia.

Horton MEK. 2019. The Orphan Child: Humanities in Modern Medical Education. Philosophy, Ethics, and Humanities in Medicine. 14 (1): 1-6.

Hasibuan, S. (2019). The Effect of Health and Religious Beliefs on Consumer Consciousness of Using Halal Cosmetics. Budapest International Research and Critics InstituteJournal (BIRCI-Journal). P. 239-249.

Jacobalis S. 2005. Pengantar tentang perkembangan ilmu kedokteran, etika medis dan bioetika. Penerbit Sagung Seto. Cetakan I. Jakarta.

Jones DS. 2014. A Complete Medical Education Include The Art And Medical Humanities. American Medical Association Journal of Ethics. 16(8) : 636-641.

Jonsen, A.R., Siegler, M., Winslade, W.J. 2010. Clinical Ethics a Practical Approach to ethical Decisions in Clinical Medicine.7th ed. The McGraw Hill Companies. New York.

KKI (Konsil Kedokteran Indonesia). 2019. Standar Nasional Pendidikan Profesi Dokter Indonesia. Jakarta.

Koenig HG. 2004. Religion, Spirituality, and Medicine: Research findings and Implication for Clinical Practice. Southern Medical Journal. 97(12).

Lari S.M.W. 2001. Etika dan Pertumbuhan Spiritual. Penerbit Lentera. Cetakan 1. Jakarta.

Macnaugton J. 2000. The Humanities in Medical Education: Context, Outcome dnd Structures. J Med Ethics: Medical Humanities. 26: 23-30.

Ondigo YMA. 2010. Forty Hadits on Good Moral Values with Short Commentaries. International Islamic Publishing House. Riyadh.

Ramadhan M. 2004. Karakteristik Dokter Muslim. Cet-I. Penerjemah Awaluddin I. Jakarta. Pustaka Al-Kautsar.

Saphiro J, Coulehan J, Wear D, Montello M. 2009. Medical Humanities and Their Discontents: Definitions, Critique and Implications. Acad Med. 84 (2): 192-198.

Silenzo VMB, Irvine CA, Sember RE, Bregman BE. 2006. Film and narrative medicine: cinemeducation and the development of narrative competence. Cinemeducation. Edited by Matthew Alexander et al. Radcliffe Publishing ltd. United Kingdom. 9-18.

Suryadi T. 2017. Aplikasi muatan area profesionalitas luhur berbasis keislaman pada kepaniteraan klinik ilmu kedokteran forensik di FK Unsyiah/ RSUD dr.Zainoel Abidin Banda Aceh. Proceeding PIT PDFI Pekanbaru. 286-291.

Wald HS, McFarland J, Markovina I. 2014. Medical Humanities in Medical Education and Practice. Medical teacher. 41 (5): 492-496.

Wong YF, Lin SJ, Cheng HC, Hsieh TH, Tsiue TR, Chung HS, et al. 2012. The formation and performance of medical humanities by interns in a clinical. Tzu Chi Medical Journal. 24: 5-11. 